African Journal of Biomedical Research, Vol. 10 (2007); 183 - 187

ISSN 1119 - 5096 @ Ibadan Biomedical Communications Group

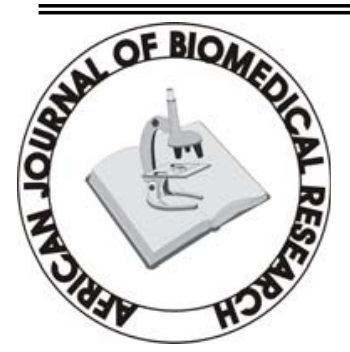

Full Length Research Article

\title{
Prevalence of Pseudomonas aeruginosa in Clinical Samples and its sensitivity to Citrus Extract
}

Full-text available at http://www.ajbrui.com http://www.bioline.br/md http://www.ajol.com

Received:

November 2006

Accepted (Revised): March 2007

Published

May 2007

\author{
${ }^{1}$ Adedeji G. B., * Fagade O. E ${ }^{2}$ and Oyelade A. $\mathrm{A}^{2}$ \\ ${ }^{1}$ Department of Medical Microbiology and Parasitology Wesley Guild Hospital, \\ Ilesha, Osun State. \\ ${ }^{2}$ Environmental Microbiology and Biotechnology Unit, Department of Botany \\ and Microbiology University of Ibadan, Ibadan.
}

\begin{abstract}
The prevalence of selected pathogens in four hundred and ninety eight samples of ear, wound swabs and urine samples submitted to the Microbiological Laboratory of Wesley Guild Hospital, Ilesa, Nigeria was investigated. In ear infections, Pseudomonas aeruginosa predominated (50\%), followed by Staphylococcus aureus (30\%) and others (20\%). In wound swabs, S. aureus predominated (46.3\%), P. aeruginosa(16\%). Other bacteria isolated included Klebsiella spp, Proteus spp and Escherichia coli accounting for $18 \%$. In urine, S. aureus and E. coli were more frequently isolated with $49 \%$ and $23 \%$ respectfully. The antibiogram studies showed that P. aeruginosa, was highly sensitive to Ciprotab, Perflotab and Gentamycin except Pseudomonas isolates from wounds which were resistant to Gentamycin. The isolates were resistant to Streptomycin, Ampicillin and Cotrimoxazole (septrin). Citrus juice C. aurantifolia (Lime) and C. limon (Lemon) on P. aeruginosa gave positive results with lethal effects on the test organisms with zones of inhibition ranging from $7 \mathrm{~mm}-22 \mathrm{~mm}$ in diameter around the colonies.
\end{abstract}

(Afr. J. Biomed. Res. 10: 183 - 187)

Keywords: Pseudomonas aeruginosa, prevalence, citrus extract, antibiogram

*Address for Correspondence (e-mail): sekiteri2002@yahoo.com

Abstracted by:

African Index Medicus (WHO), CAB Abstracts, Index Copernicus, Global Health Abstracts, Asian Science Index, Index Veterinarius, Bioline International , African Journals online 


\section{INTRODUCTION}

The genus Pseudomonas comprises of more than 140 species, only few of these are pathogenic to man. The others are essentially saprophytic and occur widely in nature (Crackshank et. al., 1975). Most infections with this organism occur in compromised hosts. The pathogenicity of these organisms is based on its ability to produce a variety of toxins and proteases. It also depends upon its ability to resist phagocytosis (Baltimore, 2000). Between 5 and 30\% of normal individuals have pseudomonas in their gastro intestinal tracts but the organisms rarely predominate (Baker and Breach, 1980). The pathogens most frequently encountered from cultures of ear infections are Pseudomonas spp, Staphylococcus aureus, Proteus spp, Streptococcus spp and Haemophillus spp. (Keith et. al, 1978, Bailey et. al, 1974). Toda (2002) described $P$. aeruginosa as being notorious for its resistance to antibiotics and for this, it is a dangerous and dreaded pathogen. The only antibiotic agents to which strains are regularly sensitive are gentamycin, carbenicillin, and polymyxin, colistin, streptomycin, quinolones, cephalosporin but ranging degree of cross resistance between these agents have been reported.

In Nigeria, a lot of the rural populace still rely much on herbs for their health care needs, though it is used blindly as therapeutics for human and animal diseases (Peach and Tracey, 1955; Benjamin et. al, 1983). Some of these herbs include Citrus aurantifolia (lime), Citrus limon (lemon) and Citrus paradissi (grape fruit). Oboh et al., (1995) reported that citrus aurantifolia juice has been used in various Nigerian home because of its anti microbial effect against some gram negative and gram positive bacteria. Jacob, (1972) discovered grape fruit seed extract to prevent a wide range of pathogens from building up a resistance in the body. Umezuruike (2003), reported that grape fruit seed extract is very effective in treating Staphylococcus, Streptococcus, Salmonella, ear infections and traveler's diarrhea. Hage's et al., (2002), investigated the antimicrobial and toxicological properties of lemon and found lemon to posses significant antimicrobial activity against Staphylococcus, Klebsiella, Escherichia coli, Pseudomonas and Candida albicans.
This work is aimed at determining the prevalence of $P$. aeruginosa species in selected clinical samples in Wesley Guild Hospital, Ilesha, study the antibiogram profile of pseudomonas strains and determine the efficiency of citrus extract on $P$. aeruginosa isolated.

\section{MATERIALS AND METHODS}

\section{Sample Collection Techniques}

Four hundred and ninety eight samples of ear, wound swabs and urine samples submitted to the Microbiological Laboratory of Wesley Guild Hospital, Ilesa, Nigeria were used for this study

Urine samples were collected in sterile universal bottles; patients suffering from urinary tract infection were instructed on how to collect a cleanproof universal container. Specimens of ear discharge and eye were collected using sterile cotton swab sticks by the assistance of medical officer. Wounds swabs high vagina swabs (HVS) and Endocervical swabs were collected using sterile swabs sticks. Cerebrospinal fluid (CSF) samples were collected aseptically by medical officer into sterile universal containers. Blood specimens were collected from patients suffering form septicemia. Unlike other samples, blood samples were collected at the time the patients temperature began to rise from normal body temperature.

\section{Isolation Procedures}

Urine: Samples were mixed thoroughly by inverting the container several times, using a sterile wire loop, the sample was inoculated on dried CLED (Oxoid) agar plates. The plates were incubated over night at $37^{0} \mathrm{C}$,

Ear discharges, eye swabs and wound swabs: The swabs were streaked on sterile Chocolate agar, and MacConkey (Oxoid) agar plates by first made primary inoculum and then streaked out using sterile wire loop to give a discrete colonies. The plates were incubated at $37^{\circ} \mathrm{C}$ for 24 hours. Suspected colonies were stored on slant for further tests.

HVS and ECS: The swabs were streaked on sterile chocolate agar and MacConkey agar plates by first made primary inoculum and then streaked out using sterile wire loop to give discrete colonies. The 
plates were incubated at $37^{\circ} \mathrm{C}$ for 24 hours suspected colonies were stored on slant for further tests.

CSF: CSF specimens were inoculated chocolate agar plates and MacConkey agar plates. Chocolate agar plates were incubated in $10 \% \quad \mathrm{CO}_{2}$ and MacConkey agar plates were incubated at $37^{0} \mathrm{C}$ for 24 hours and then observed for suspected colonies.

\section{Characterization of Isolates}

Characterization of isolates was carried out by employing macroscopic, microscopic, physiological, serological and biochemical tests.

\section{Antibiotic Sensitivity Test Preparation of Inoculum}

Organisms under test (pure isolates) were inoculated into $4 \mathrm{ml}$ of peptone broth and incubated at $37^{\circ} \mathrm{C}$ for 2-5 hours and adjusted turbidity to match an opacity tube containing $0.5 \mathrm{ml}$ of $1 \%$ barium chloride in $1 \%$. Sulphuric acid (N/36) to give a standard inoculum used in seeding the plates for sensitivity testing (Clark et al., 1981).

\section{Sensitivity Testing}

Susceptibility of the isolates to antimicrobial agents was determined by the agar diffusion techniques using Kirby-Bauer disc method (Prescolt et al., 2002) commercially prepared antibiogram doses in (microgram [mcg]) contained in 10 tiped compound susceptibility disk with there corresponding concentrations were used.

\section{Determination of the Effect of Citrus Extracts on the Strains of $P$. aeruginosa}

Preparation of Citrus Extracts: Citrus aurantifolia (lime) C. limon (lemon) and C. paradissi (grape fruit) were washed in running tap water in the laboratory surface sterilized with 70\% alcohol and then rinsed with sterile distilled water. The fruit were peeled and cut diametrically; juice was expressed into a sterile universal container separately and then filtered into another sterile container to remove the seed and other tissues. Double fold dilution of juices was made with sterile distilled water to give $1 / 2$ and $1 / 4$ strength.

\section{Seed Extracts}

The seeds of the grape fruits were air-dried for two weeks to prevent loss of active components. They were ground into powder with electric blender. Absolute ethanol and methanol were used for the extraction. Varied concentrations (0.5, 0.75, $1.0 \mathrm{mg} / \mathrm{ml}$ ) were made by dissolving them in one milliliter of each of the solvent ad then soaked over night.

\section{Screening of Citrus Extracts for Antimicrobial Activities \\ Screening for antimicrobial activities of each citrus extract on each of the test organism used in this investigation was carried out using the methods of Clark et al., (1981); and Toda et al., (1989).}

\section{RESULTS}

Four hundred and ninety-eight clinical samples were collected form children's welfare clinics and adults' wards including out patients clinic of Wesley Guild Hospital Ilesa, Osun State (Table 1).

The distribution of different pathogens ( $P$. aeruginosa, Staph.aureus, Proteus spp, Klebsiella spp and Escherichia coli) isolated from different samples is as shown in table 2. Pseudomonas aeruginosa was isolated from most of the samples tested followed by $S$. aureus and Proteus spp, Klebsiella spp and E. coli.

Table 1: Source and number of different samples used

\begin{tabular}{|c|c|c|c|}
\hline Samples & Children & Adults & Total \\
\hline Ear swabs & 33 & 7 & 40 \\
\hline Wound swabs & 12 & 23 & 35 \\
\hline Urine samples & 12 & 151 & 163 \\
\hline Blood & 64 & 13 & 77 \\
\hline $\begin{array}{ll}\text { Cerebrospinal fluid } \\
(\mathrm{CSF})\end{array}$ & 45 & 0 & 45 \\
\hline $\begin{array}{l}\text { Endocerviccal swab } \\
\text { (ECS) }\end{array}$ & 0 & 39 & 39 \\
\hline $\begin{array}{l}\text { High vaginal swab ( } \\
\text { HVS) }\end{array}$ & 1 & 29 & 30 \\
\hline Eye swab & 6 & 1 & 7 \\
\hline Semen & 0 & 5 & 5 \\
\hline Sputum & 0 & 55 & 55 \\
\hline Catheter tip & 0 & 2 & 2 \\
\hline TOTAL & & & 498 \\
\hline
\end{tabular}


The results of distribution of pathogens from different samples are as shown in table 2. It was observed that $P$. aeruginosa was the most incriminating pathogens of the ear infection account for $50 \%$ of the total number of isolates. Others are S. aureus (30\%) Proteus sp (14\%) Klebsiella spp (2\%) and E. coli (2\%). With $46.3 \%$, followed by $P$. aeruginosa (16\%) while Klebsiella account for $17 \%$ of the total number. Percentage is based on total number of isolates.

Table 2:

Distribution of different pathogens

\begin{tabular}{llll}
\hline Organisms & $\begin{array}{l}\text { Otitis } \\
\text { media }\end{array}$ & $\begin{array}{l}\text { Wound } \\
\text { swab }\end{array}$ & urine \\
\hline P. aeruginosa & $25(50)$ & $7(16)$ & $9(8.7)$ \\
\hline S. aureus & $15(30)$ & $19(46.3)$ & $51(49)$ \\
\hline Proteus spp & $7(14)$ & $3(7.3)$ & $5(4.8)$ \\
\hline Klebsiella spp & $1(2)$ & $7(17)$ & $24(23)$ \\
\hline Escherichia coli & $1(2)$ & $5(12.2)$ & $15(14.4)$ \\
\hline No growth & 1 & 3 & 71 \\
\hline
\end{tabular}

Urine culture showed that $S$. aureus and E. coli were more frequently isolated with $49 \%$ and $23 \%$ respectively while Klebsiella account for $14.4 \%$ and P. aeruginosa (8.7\%).

Results of comparative antimicrobial activity of citrus extracts with commercial antibiotics disc were shown on Table 3.
The best antimicrobial activity was observed in the juice of lime and lemon. They were active against all stain of $P$. aeruginosa tested, Citrus aurantifolia (lime) which produced wider zone of inhibition ranging from $7 \mathrm{~mm}$ to $21.5 \mathrm{~mm}$ at the double dilution of $1 / 2$ and $1 / 4$ The grape fruit juice showed little or no significant antimicrobial activity against the test organisms.

Methanol and ethanol extracts of grape fruit seed did not show any antibacterial activity. The juice of both lime and lemon had better antibacterial activity and compared favourably to the commercial antibiotic disc.

\section{DISCUSSION}

In this study, the incidence of P. aeruginosa was found to be $50 \%$ in patients with Otitis media from the total number (40) investigated Staph aureus followd with the incidence of $30 \%$ while Proteus ranked third with incidence of $14 \%$. These results are similar to the findings of Ogisi and Osamar (1982). They reported a prevalence of $31 \%$ and 24\% for Pseudomonas spp and Proteus spp respectively while Colar et. al., (1983) reported a prevalence of $38 \%$ and $9.8 \%$ for Pseudomonas spp and Proteus spp respectively.

Table 3:

Comparative antimicrobial activity of citrus extracts with commercial antibiotics disc

\begin{tabular}{|c|c|c|c|c|c|c|c|c|c|c|c|c|}
\hline \multirow{2}{*}{\multicolumn{9}{|c|}{$\frac{\text { A }}{\text { Inhibition Zone (mm) }}$}} & \multicolumn{4}{|l|}{ B } \\
\hline & & & & & & & & & GEN & COL & CIP & PER \\
\hline \multirow{2}{*}{$\begin{array}{l}\text { P.aeruginosa } \\
\text { strains from } \\
\text { ear }\end{array}$} & \multicolumn{2}{|c|}{ Lemon juice } & \multicolumn{2}{|c|}{ Lime juice } & \multicolumn{2}{|c|}{ Grape juice } & \multirow{2}{*}{$\begin{array}{l}\text { Seed } \\
\text { ethanol } \\
\text { extract }\end{array}$} & \multirow{2}{*}{$\begin{array}{l}\text { Methanol } \\
\text { extract }\end{array}$} & & & & \\
\hline & $1 / 2$ & $1 / 4$ & $1 / 2$ & $1 / 4$ & $1 / 2$ & $1 / 4$ & & & & & & \\
\hline 3292 & 13 & 7 & 16 & 14 & - & - & - & - & - & 15 & 13 & - \\
\hline 3291 & 17 & 12 & 17 & 13 & - & - & - & - & - & 13 & 20 & - \\
\hline 1450 & 17 & 16 & 20 & 17 & - & - & - & - & 16 & 15 & 33 & 27 \\
\hline 2374 & 16 & 12 & 21 & 14 & - & - & - & - & 7 & - & 25 & 20 \\
\hline 1808 & 17 & 11 & 17 & 13 & 6 & 4 & - & - & 16 & 14 & 35 & 21 \\
\hline 1528 & 15 & 9 & 17 & 11 & - & - & - & - & 14 & 12 & 22 & 16 \\
\hline 2540 & 20 & 18 & 21 & 19 & 12 & - & - & - & 17 & 12 & 37 & 25 \\
\hline 2791 & 22 & 20 & 22.5 & 21 & - & - & - & - & - & - & 33 & 22 \\
\hline 351 & 19.5 & 15 & 20 & 15 & - & - & - & - & - & - & 30 & 210 \\
\hline
\end{tabular}


The results obtained also agreed with the findings of Selina (2002) who rated $P$. aeruginosa as the most common bacteria isolated from mild to severe form of external otitis and chronic supprative otitis media.

The values of $16 \%$ and $46.3 \%$ prevalence of Pseudomonas and Staphylococcus aureus obtained in wound swabs investigated were similar to the study, Pseudomons was found to be the most commonly cultured organism (54.2\%) followed by S. aureus (20.8\%). The slight difference may be due to geographical factors and also duration of the investigation. Investigation on other samples such as blood, CSF, HVS, ECS and semen showed little or no significant involvement of Pseudomonas.

The sensitivity pattern of the organisms to Gentamycin, Ciprotab, Perflotab in this study were comparable to the values of $92 \%, 88 \%$ and $59 \%$ as respectively obtained by Ikeh et al.. (1993). But the high in-vitro sensitivity recorded for ciprotab and perflotab (quinolones) may not serve useful purpose in children because quinolones are usually contra indicated as paediatric regimens because of side effects in children and they are expensive for adult use.

Extracts of citrus fruits especially lime and lemon showed high antibacterial activity against all the pseudomonas strains tested (Table 3). This suggests that the citrus juice contains active ingredient which qualify them for medicinal use. Lime juice has been locally applied on wounds and accidental cuts or abrasions in various Nigerian homes with the belief that this will speed up healing (Walker, 1953).

\section{REFERENCES}

Bailey, W.R., Scott E.G. (1974): Diagnostic Microbiology, 4th Ed. C.V. Mosley Company. St. Louis. Pp. 99-175.

Baker and Breach M.R. (1980): Medicinal Microbiological Techniques $1^{\text {st }}$ Ed. Butterworths LondonBoston. Pp 142-143.

Baltimore R.S. (2000). Pseudomonas in Nelson Textbook of Pediatrics 862-8664.

Clark, A.M. El Feraly, F.S. and LI, W.S. (1981). Antimicrobial activity of Phenolic Constituents of Magnolia grindiflora. L.J. Pharm. Sci. 70: 951-952.
Coker, A.O. Ijaduola, G.T.A. and Odugbemi, T.O. (1983). Bacterial isolates from chronic discharging Ears in Nigerian Children. E. Afr. Med. J. 60: 462-466.

Cruickshank, R.J.P., Duguid, B.P, Marmion and Swain, R.H.A., (1975)). Medical Microbiology 12th Ed. Vol.11. Churchill Living Stone Edinburgh London and New York. Pp: 195-200.

Hayes, A.J., Markovic, B. (2002). Toxicity of Backhousia citriodora (Lemon myrthle). Antimicrobial and invitro cytoxicity: Food and Chem. Toxicol. 40: (4). 535-543.

Ikeh, E.I. Adebayo, E.O. Okuonghae, H.O. and Ighogboja, L.S. (1993). Bacteriology of chronic discharging ears in children in Jos. Nig. J. Med. Lab Sci. 3: 27-30.

Jacpb Harick (1972). The Guardian Newspaper (July 3, 2003). How Grapefruit seed extract stops germs, salthypertension. Pp31.

Kaushik R., Kumar S., Sharma R (2001). Bacteriology and burn wounds, the first 3 years in a new born unit at the Medical College Chandigarh. Burns 27 (6): 595-597.

Keith, H.R. Bluestone, C.D. Richard, H.M.(1978). Microbiology or Recurrent and Chronic Otitis Media with effusion. J. Paediatr . 93: 739-745.

Oboh, P.A. Agbonlahor,D. E., Ekundayo A.O., OwheUrughe, U.B. (1995). Antibacterial activity of Citrus arantifolia (Lime) juice against some Gram positive and Gram negative bacteria. Nig. Ann. Nat. Sci. 2: 1-9.

Ogisi, F.O. and Osamar, Y.Y. (1982). Bacteriology of Chronic Otitis media in Benin. Nig. Med. J. 12: 187-190.

Peach, K. and Tracy, M.V.(1955). Modern Methods of Plant Analysis Springer Verlag, Berlin 3: p. 626.

Prescott, L.M., Harley, J.P. and Klein D.A. (2002). Microbiology 5th edn; McGraw-Hill. New York, N.Y. 10020 pp. 809-811.

Selina, C. (2002). Pseudomonas infection Emeducine Worldi Medical Library pp. 1-10.

Toda, M. Okubo, S. Hijoshi, R. and Shimamora, T. (1989). The bacteriocidal activity of tea and coffee leaf. Appl. Microbiol. 8: 123-133.

Todar, K. (2002). Todar's online textbook of Bacteriology www.pseudomonas. Intm. Pp. 1-8.

Umezurninke (2003). The Guardian Newspaper (July 3 2003). How Grape fruit seed extract stops germs, salthypertension. P.31.

Walker, A. R. (1953). A: Usages Pharmaceutiques des plantes spontanees du Gabon, 11 Bull. Inst. Etudes. Centrafr. No.5: 19-40. 